\section{Käsikirja kielen opettajalle ja tutkijalle}

Taina Saarinen, Pirkko Nuolijärvi, Sari Pöyhönen \& Teija Kangasvieri (toim.) (2019). Kieli, koulutus, politiikka. Monipaikkaisia käytänteitä ja tulkintoja. Vastapaino. 320 sivua.

KOULUTUSPOLIITTISEEN keskusteluun monipuolisesti kantaa ottava Kieli, koulutus, politiikka on käsikirja kieltä kouluttaville ja tutkiville. Teoksesta osa keskittyy perusopetusta koskevaan kielikoulutukseen, mutta aikuiskoulutuksen kieltenopettajille ja -tutkijoille on kaikissa kirjan luvuissa olennaisia näkökulmia, oivaltavia verbalisointeja ja uutta pohdittavaa.

Kirjassa on johdannon lisäksi kymmenen lukua. Niissä käsitellään suomalaista kieli- ja koulutuspoliittista todellisuutta kolmeen pääteemaan sitoen: poliittista kieltä, koulutuksen suuria ja pieniä linjoja sekä työelämää ja siihen integroitumista.

\section{ASIANTUNTEVUUS VAKUUTTAA}

Oppikirjaksi teos tekijöiden mukaan soveltuisi esimerkiksi eri kielten opiskelijoiden maisterivaiheeseen - oma arvioni on, että ainakin Helsingin yliopiston kielten kandiohjelmankin opiskelijat hyötyisivät kirjan lukemisesta opinnäytetöiden aiheita valitessaan. Vankkaan tutkimustietoon perustuvana ja kansainväliseen sosiolingvistiikkaan ja muihin kieli- ja koulutuspolitiikkaa tutkiviin tieteisiin viittaavana teos on omiaan jäntevöittämään myös tutkijoiden ajattelua ja sanoittamista kielen, koulutuksen ja politiikan aiheista.

Kirjan vahvuuksiin kuuluvat asiantuntevat ja huolella laaditut luvut ja niiden kautta välittyvän keskustelun monipuolisuus. Oman alani opiskelija voisi perehtyä esimerkiksi kielellisten oikeuksien ja ryhmien, kuten kansalliskielten ja kielellisten vähemmistöjen, määritelmiin laeissa ja Suomessa merkittävissä teksteissä. Tässä ajattelen erityisesti Pasi Ihalaisen, Pirkko Nuolijärven ja Taina Saarisen kirjoittamaa lukua "Kamppailua tilasta ja vallasta - kieli- ja koulutuspolitiikan historiallisesti kierrätetyt diskurssit" sekä Petteri Laihosen ja Mia Halosen kirjoittamaa lukua "Vähemmistöt ja enemmistöt kieliideologisina käsitteinä”.

Halutessaan kirjoittajien tarkastelutapoja voi soveltaa opiskeltavan kielen vastaaviin teksteihin. Itselleni Ari Huhdan ja Sari Aholan "Arviointi kielipoliittisena ja kielikoulutuspoliittisena toimintana" avasi sitä, millä sanoilla olisin voinut kuvata yliopistopedagogiikan kurssillani arviointia omassa opetuksessani.

Yliopistolla luokkahuonettani tai auditoriotani olen harvemmin analysoinut kielipoliittisena tilana, mutta sitähän se toden totta onkin, kuten Niina Lilja, Karita Mård-Miettinen ja Tarja Nikula osoittavat luvussa "Luokkahuone

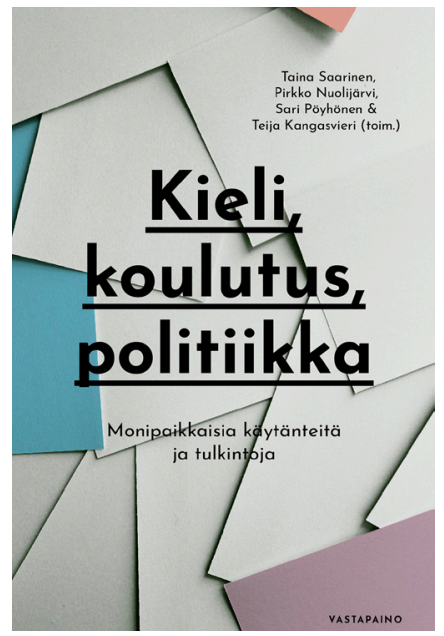

kielipoliittisena ja kielikoulutuspoliittisena tilana”. Monikielisessä työyhteisössäni näen samankaltaisia haasteita ja onnistuneita käytäntöjä, joita Aija Virtanen ja Mia Raitaniemi kuvaavat luvussa "Туöelämän kielikäytänteet monikielisissä yhteisöissä”.

\section{AINEKSIA YHTEISKUNNALLISEEN KESKUSTELUUN}

Pidän teosta eheänä ja kiinnostavana kokonaisuutena. Se pyrkii tarjoamaan esimerkiksi aineenopettajan pätevyyteen tähtääville opiskelijoille, perus- ja toisen asteen kieltenopettajina toimiville sekä heitä kouluttaville työkaluja yhteiskunnalliseen keskusteluun tarttumiseksi. Luvut suomalaisesta koulutuspolitiikasta ja kielenopettajien rooleista sopivat erityisen hyvin tälle kohderyhmälle.

Teoksen uusia avauksia on erityisesti Sirpa Leppäsen, Heidi Vaaralan ja Peppi Taalaksen "Sosiaalinen media - mahdollisuuksia ja haasteita kielikoulutuspolitiikalle". 


\section{LUOKKAHUONE ON KIELIPOLIITTINEN TILA.}

Yliopiston kieltenopetuksessa voitaisiinkin yhdistää sosiaalisen median käyttäminen, mikä näinä päivinä näyttää olevan yksi opiskelijoiltamme edellytetty työelämätaito, ja kielen oppiminen uusilla tavoilla. Toinen uusi avaus on Sari Pöyhösen, Minna Sunin ja Mirja Tarnasen "Kieli kotouttamispolitiikan ytimessä - aikuisen maahan- muuttajat matkalla työelämään”.

Suosittelen teosta kollegoilleni ja toivon, että sitä käytettäisiin muuallakin kuin opettajankoulutuksessa. Kielen ja yhteiskunnan suhteita käsittelevään opetukseen kirja sopii oheislukemistoksi, ja kieltä aikuisille opettavien kannattaa lukea teosta oman ammattipätevyyden lisäämiseksi.
JOHANNA VIRKKULA

yliopistonlehtori kielten osasto, Helsingin yliopisto

(D) https://orcid.org/0000-00022821-2246

\section{Kaikkien-malli}

Vaikuttava ja oppijalähtöinen perustaitojen koulutusmalli työikäisten arjen parantamiseksi.

- Oppijalähtöisyys ja vaikuttavuus: Sisältö ja tavoitteet suunnitellaan yhdessä oppijoiden kanssa. Oppija valitsee ja aikatauluttaa arkensa parantamiselle henkilökohtaisen tavoitteen. Tavoitteen saavuttamiseksi on käytettävä yhtä tai useampaa perustaitoa. Tarve arjen parantamiseen motivoi, antaa oppimiselle syyn ja suunnan.

- Paikallisuus. Koulutus linkitetään paikalliseen yhteisöön. Vahvistetaan oppijoiden yhteyksiä toimintaympäristöönsä.

- Skaalautuvuus. Sopii käytettäväksi erilaisissa ympäristöissä ja kanavissa, esimerkiksi harrastusryhmässä tai etäkoulutuksena.

Yhteiskunta tarvitsee kaikkia - perustaidot kuuluvat kaikille

Kaikkien-malli

Kaikkien-mallin esittely ja kouluttajan opas käyttöönottoon:

kansalaisenperustaidot.fi / kaikkienmalli.fi

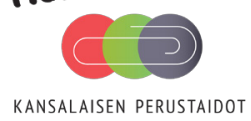

